\title{
PRESENT STATUS OF THE MAIN SHADS' POPULATIONS IN PORTUGAL.
}

\author{
M.J. COSTA (1), P.R. ALMEIDA (1, 2), I.M. DOMINGOS (1), J.L. COSTA (1), \\ M.J. CORREIA (1), M.L. CHAVES (1), C.M. TEIXEIRA (1)
}

(1) Instituto de Oceanografia - Faculdade de Ciências da Universidade de Lisboa, R. Ernesto de Vasconcelos - Campo Grande, 1749-016 LISBOA, Portugal.

E-mail : zitasia@fc.ul.pt.

(2) Universidade de Évora, Departamento de Biologia, Pólo da Mitra, 7002-554 ÉVORA, Portugal.

\begin{abstract}
The allis shad (Alosa alosa) and the twaite shad (Alosa fallax) are anadromous migratory species, which are threatened not only in Portugal but also in most of their geographic area of distribution. Overfishing and illegal fishing, pollution, physical barriers and river-bed changes seem to be the main reasons for the populations gradual decline. The progressive reduction in the numbers of anadromous fish registered in the last decades in some Portuguese river basins requires urgent action, namely the implementation of measures to promote the recovery of those populations. The current status of shads populations in Portugal is discussed, and the distribution along the main Portuguese watersheds and major threats to these species are presented, as well.
\end{abstract}

Key-words : shads, Alosa alosa, Alosa fallax, conservation, Portugal.

\section{L'ÉTAT DE CONSERVATION DES PRINCIPALES POPULATIONS DES ALOSES AU PORTUGAL.}

\section{RÉSUMÉ}

La grande alose (Alosa alosa) et l'alose feinte (Alosa fallax) sont des poissons migrateurs anadromes menacés non seulement au Portugal mais dans toute leur aire de distribution géographique. La surexploitation et la pêche illégale, la pollution, les obstacles physiques et les modifications du lit des rivières semblent être les principales raisons de la diminution des populations de ces espèces. Le déclin progressif du nombre de poissons anadromes au cours des dernières décades, et cela dans plusieurs bassins, a montré la nécessité de la mise en œuvre de mesures pour récupérer leurs populations. Dans ce travail on présente l'état de conservation des aloses au Portugal, et on montre aussi leur distribution, ainsi que les principales agressions subies par les deux espèces d'alose dans les principaux bassins du pays.

Mots-clés : aloses, Alosa alosa, Alosa fallax, conservation, Portugal. 


\section{INTRODUCTION}

The allis shad, Alosa alosa (L., 1758), and the twaite shad, Alosa fallax (Lacépède, 1803), are anadromous migratory species which are threatened not only in Portugal but also in most of their geographic range (BAGLINIERE et al., 2000 ; LELEK, 1987). In what concerns important shads' populations their distribution is now restricted to some Portuguese and French rivers (QUIGNARD and DOUCHEMENT, 1991a, b).

Like for other diadromous fishes, the main causes of the severe decline of these two species in Portugal are the continuous loss of suitable habitat, the reduction of river flows, the generalised pollution of aquatic systems, the overfishing of the most important stocks and the by-catch in the illegal glass eel fisheries (ASSIS et al., 1992 ; unpublished data). According to ALEXANDRINO (1996) hybridisation between both species is also a major constraint for these fishes.

The aim of this work is to analyse the recent evolution of the shads' populations in the major Portuguese river basins and try to relate it with the most important modifications induced by human activities in these ecosystems. With that purpose, the reduction of the suitable habitat for both species due to the construction of dams and weirs during the last decades was estimated and, together with historical data for freshwater flows were compared with the fisheries statistics available for the country in order to understand their relation in each of the studied river basins. For the years with no available information of shads' fisheries, the diadromous fish landings were used as guideline, since a significant amount of these fisheries result from the capture of allis shad and twaite shad.

\section{RESULTS AND DISCUSSION}

The Douro and Tagus river basins are two good examples of the reduction of the suitable habitat for the shads (Alosa sp.) caused by the construction of dams and weirs (Figure 1). For the River Tagus the main habitat loss occurred in the 1950's with the building of two large dams, Castelo de Bode and Belver (Figures 1 and 2). Although the presence of these two infrastructures increased the regularisation capacity in this river basin, its effect on the freshwater flow natural regime became more notorious between 1965 and 1976, probably as a consequence of a drought period which resulted on the reduction of the river flow observed in that decade (Figure 3 ). Therefore, it can be assumed that the decrease in the landings of shads observed in 1955 (Figure 4) resulted mainly from the loss of habitat in this watershed. On the other hand, in the Douro river basin there was also a six-year period of low freshwater flow during the 1970's (Figure 3) that was coincident with the habitat loss associated with the building of the Carrapatelo dam in 1972 (Figures 1 and 2). We believe that this coincidence accelerated the deterioration of the shads' habitat promoting the impoverishment of both populations in the Douro during the 1970's. After the construction of the Crestuma dam in $1985(21 \mathrm{~km}$ from the river mouth), the situation became worse almost leading to the disappearance of the shads' populations from this river, as it was mentioned by ALEXANDRINO (1996).

The remaining Portuguese river basins, particularly those from the North and Centre region of the country, also present a serious habitat loss due to the building of dams in the last 50 years. According to ALEXANDRINO (1996) in the Minho river basin the major reduction in the population of allis shad occurred in the 1960's as a consequence of the construction of several large dams in Spain. 


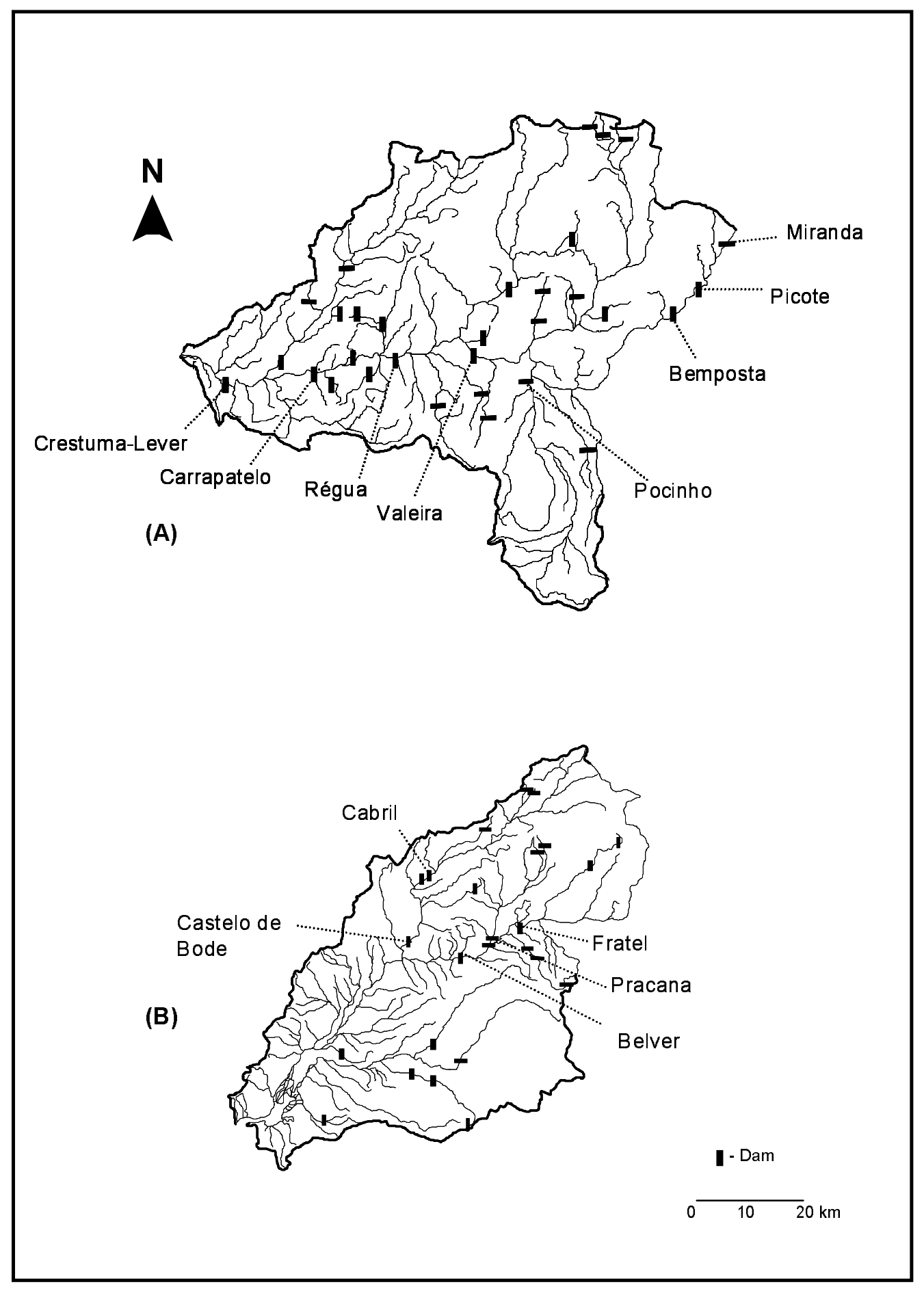

Figure 1

Localization of the dams in the Douro river basin (Portuguese part) (A) and in the Tagus river basin (Portuguese part) (B). Major dams are identified.

Figure 1

Localisation des barrages du Douro (partie portugaise) (A) et du Tage (partie portugaise) (B). Les principaux barrages sont indiquées. 


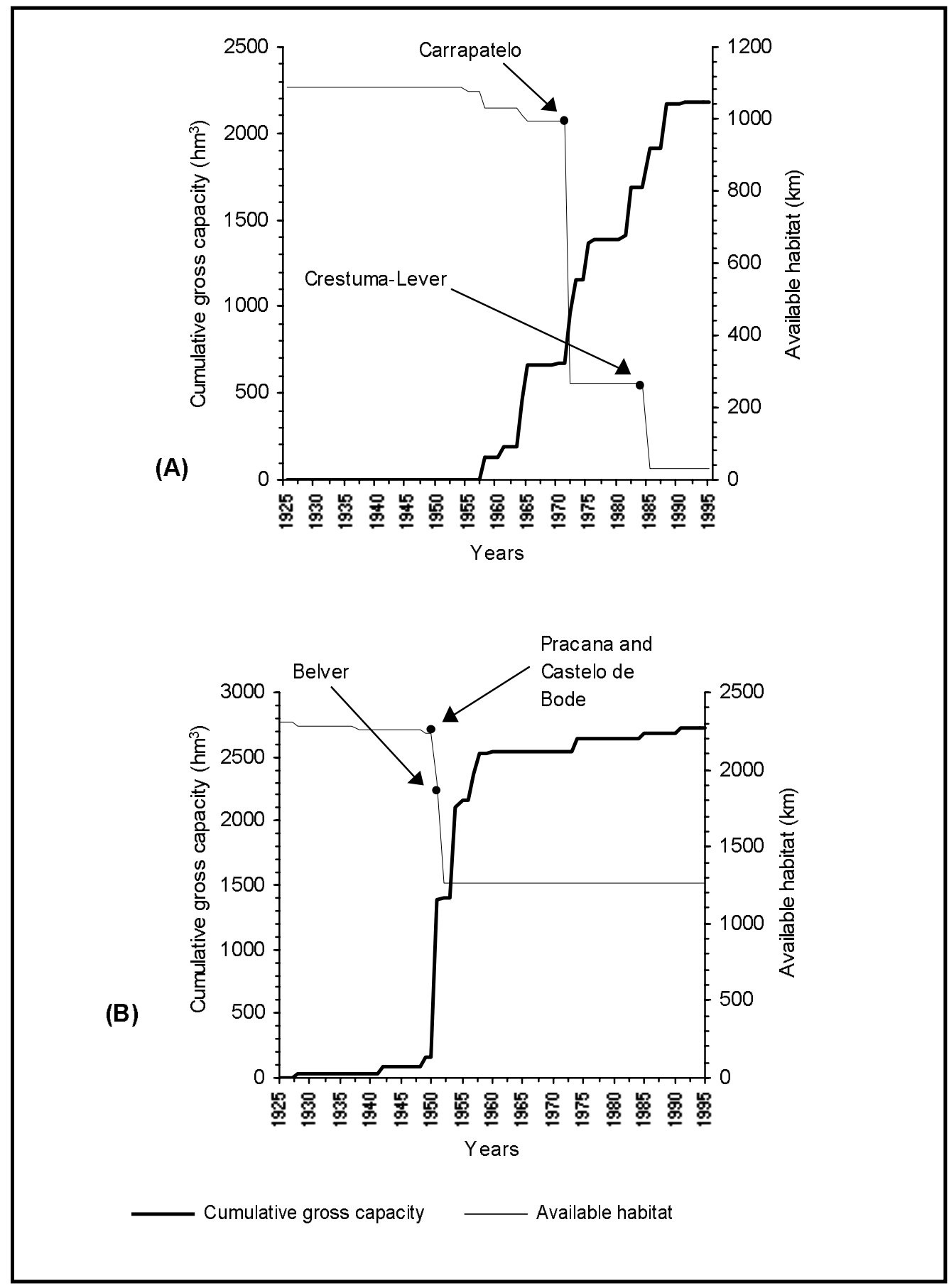

Figure 2

Cumulative gross capacity and habitat loss observed in the Douro river basin (A) and in the Tagus river basin (B). The dates of construction of large dams are shown for both basins.

\section{Figure 2}

Capacité total cumulative et réduction de l'habitat observée dans les bassins du Douro (A) et du Tage (B). Pour les deux bassins, les dates de construction des principaux barrages sont indiquées. 

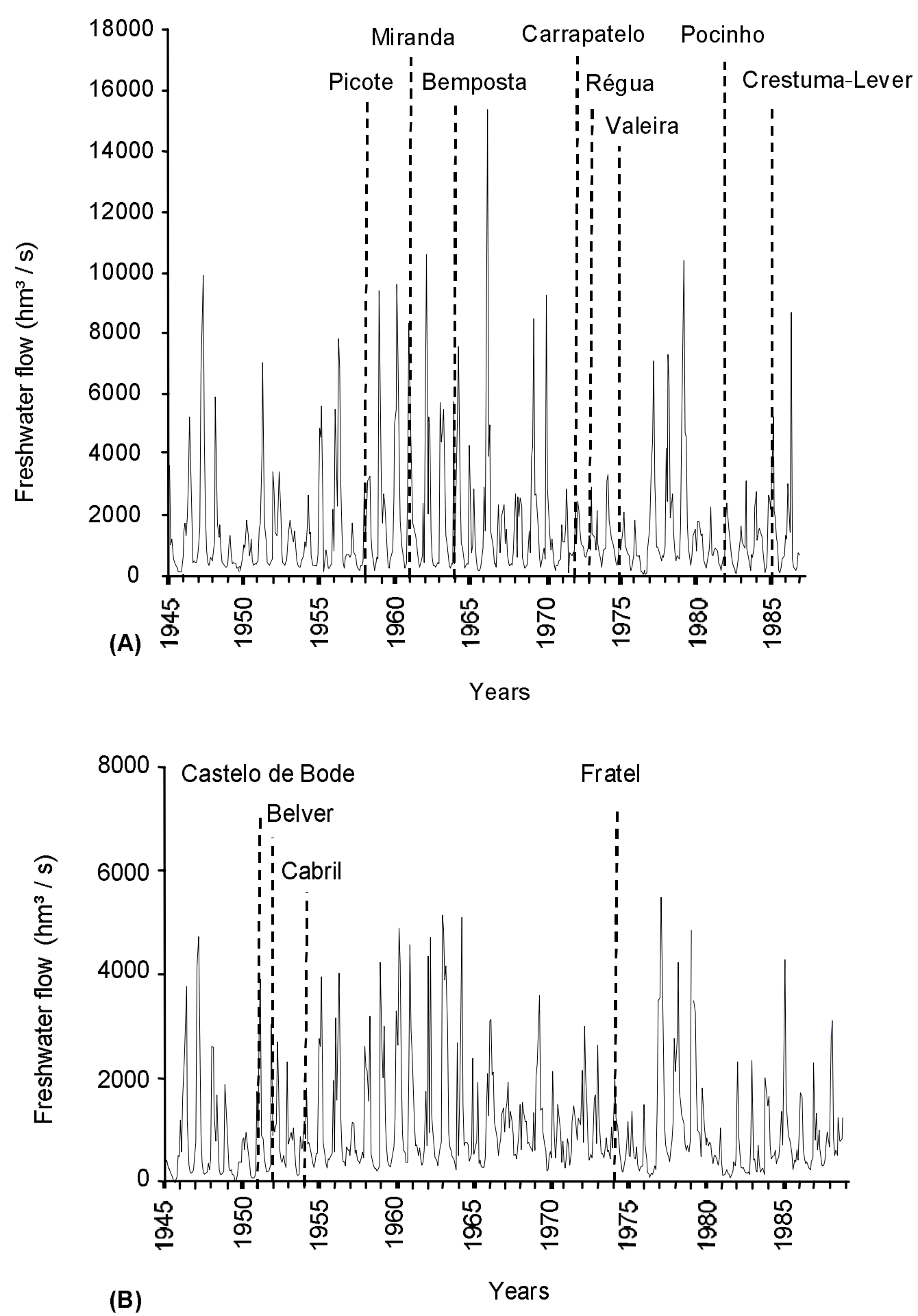

Figure 3

Monthly freshwater flow recorded at Crestuma (Douro river basin) (A) and at Santarém (Tagus river basin) (B), and construction date of major dams.

Figure 3

Débit mensuel du fleuve Douro à Crestuma (A) et du fleuve Tage à Santarém (B) et la date de construction des principaux barrages. 


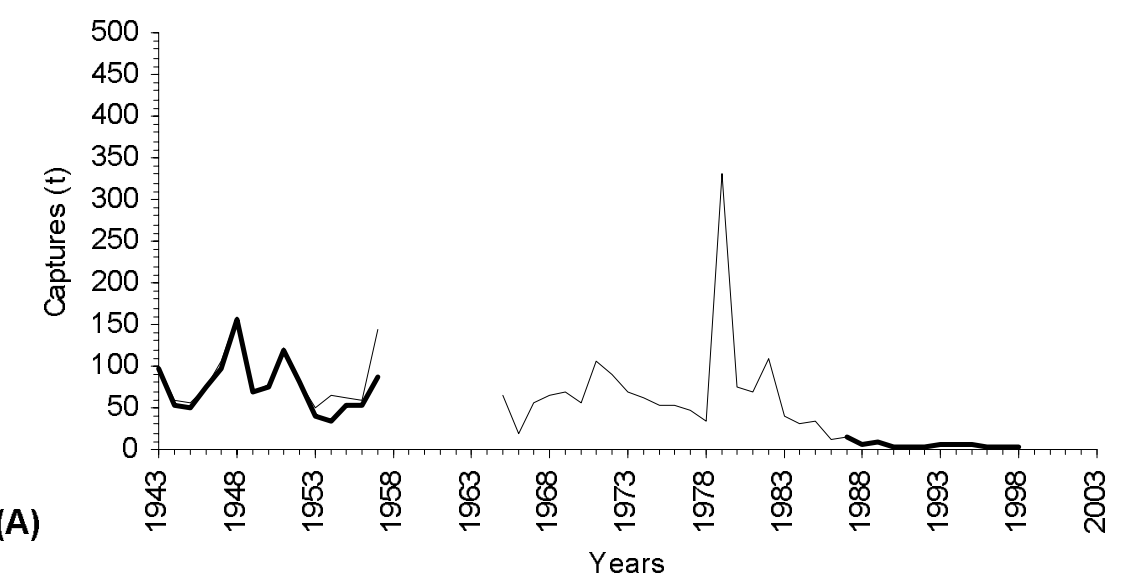

(B)

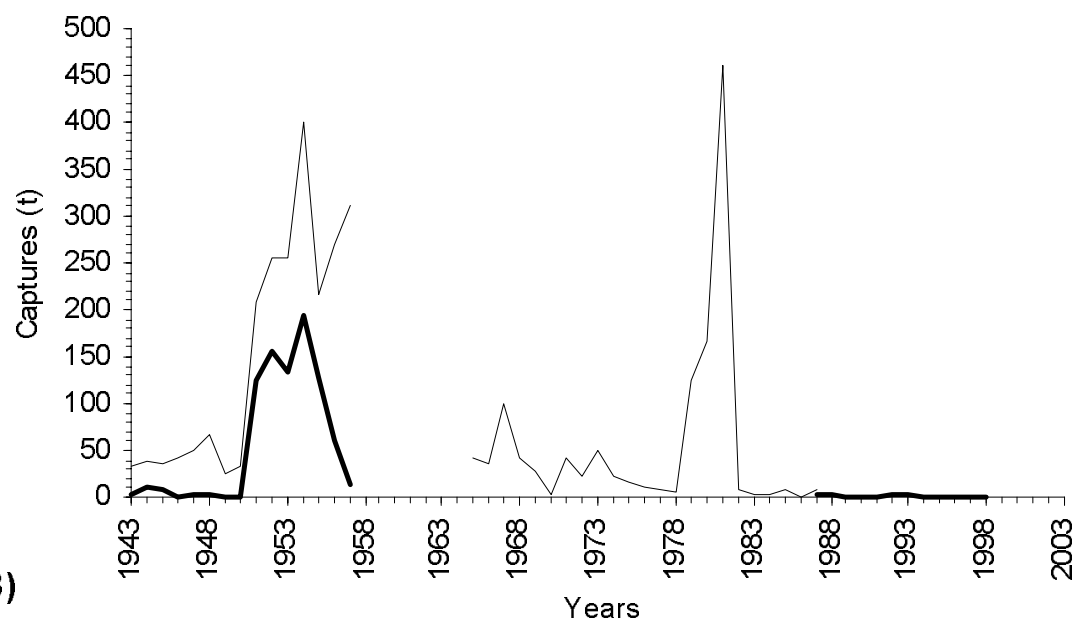

Figure 4

Allis shad, twaite shad and diadromous species fisheries in the rivers Douro (A) and Tagus (B).

Figure 4

Evolution des captures de la grande alose, de l'alose feinte et de l'ensemble des poissons diadromes dans les fleuves Douro (A) et Tage (B). 
In the River Lima the constraints for the shads' populations are related to the freshwater flow regularisation originated by the operating system of Alto Lindoso and Touvedo hydroelectric power stations built in 1993 and 1996, respectively. Recently, in 1997, a small stone weir was constructed at Ponte de Lima, located at $23 \mathrm{~km}$ from the river mouth. As a result, the professional fishermen registered a significant reduction in the shads' captures during the last three years.

The migratory route of these fishes was interrupted in the River Vouga during the 1930's with the building of the Açude da Grela dam ( $41.5 \mathrm{~km}$ from the river mouth). Twenty years ago, another stone weir was built, $9.5 \mathrm{~km}$ downstream from the first one, reducing to a greater extent the available habitat for these anadromous species. Nevertheless, both species continue to migrate to this river basin.

Shads used to migrate into the upper reaches of River Mondego, but after the construction of the Açude-Ponte dam, at Coimbra, in the early 1980's, the migratory species were prevented from passing over this obstacle, and were forced to complete their life cycle in the last $35 \mathrm{~km}$ of the river.

The lack of information for the Sado river basin does not allow a similar line of thought. However, the fishermen refer that the decline of shads' populations in this river resulted from agricultural pollution, particularly from the activities developed in the rice fields.

In the South part of Portugal, at the Mira and Guadiana river basins, the reduction of the freshwater flow has been pointed out as the main reason for the collapse of these populations.

Finally, it should be mentioned that there are two landlocked populations of allis shad, one in the Aguieira dam reservoir (Mondego river basin) and the other in the Castelo de Bode dam reservoir (Tagus river basin), that were prevented from returning to the sea after the construction of the dams, in 1981 and 1951, respectively.

\section{MANAGEMENT AND PROTECTION}

\section{Fisheries}

The fishing legislation presents problems (e.g. differences between freshwater and brackish-water legislation, insufficient control by the fishing authorities) that need to be reviewed aiming the protection of these species. However, in the last three years, the Ministry of Agriculture and Fisheries designated several river stretches in the Lima, Cávado, Vouga and Mondego watersheds as Professional Fishing Areas in order to ensure a better management of this activity.

\section{Restoration of migratory routes and rehabilitation of historical spawning sites}

The need for proper fish passages in the dams was present in the mind of the people who built some of the Portuguese larger dams. Unfortunately, the solutions adopted proved to be inadequate for our shad species. Presently, studies have been carried out in some river basins (e.g. Mondego) to install fish passages that will ensure the recolonization of upstream river stretches, known in the past as important spawning sites. 


\section{Pollution control}

In the last 15 years an effort has been made to rehabilitate riverine ecosystems in terms of water quality. Hopefully the application of the EU Water Directive standards will bring some benefits to the freshwater ecosystems.

\section{Nature conservation}

The classification of three different river stretches as Sites to include in the European Natura 2000 network (Minho, Lima and Vouga rivers), using the presence of diadromous fish as one of the criteria for the choice, will ensure the rehabilitation of these watersheds for shads and other diadromous species.

\section{CONCLUSION}

The recovery of the allis shad and twaite shad Portuguese populations is still possible and depends upon the expansion of the suitable habitat for these species. This objective can be achieved installing fish passages in selected river basins, implementing a freshwater flow adequated to the ecological needs of diadromous species, developing an efficient pollution control and water quality rehabilitation program and increasing the fiscalization of fishing activities.

\section{ACKNOWLEDGEMENTS}

This work was financially supported by FCT (Fundação para a Ciência e a Tecnologia - Project PRAXIS/2/2.1/CA/1981/95) and research grants BIIC 3584 and BIIC 3585.

\section{BIBLIOGRAPHY}

ALEXANDRINO P.J., 1996. Estudo de populações de sável (Alosa alosa L.) e savelha (Alosa fallax Lacépède). Análise da diferenciação interespecífica, subestruturação e hibridação. PhD Thesis. Oporto University, 187 p.

ASSIS C.A., COSTA J.L., MOREIRA F., ALMEIDA P.R., GONÇALVES J.J., 1992. Ameaças à sobrevivência dos peixes migradores do Tejo. Sugestões para a sua conservação. Publicações Avulsas do INIP, 17, 429-441.

BAGLINIĖRE J.L., SABATIÉ M.R., ALEXANDRINO P., APRAHAMIAN M.W., ELIE P., 2000. Les aloses: une richesse patrimoniale à conserver et à valoriser. In : BAGLINIĖRE J.L. and ELIE P. (Eds.), Les aloses (Alosa alosa et Alosa fallax spp.), INRA, Paris, 263-275.

LELEK A., 1987. Threatened fishes of Europe. Aula-verlag Wiesbaden, 343 p.

QUIGNARD J.P., DOUCHEMENT C., 1991a. Alosa alosa (Linnaeus, 1758). In: HOESTLANDT $\mathrm{H}$. (ed.), The Freshwater Fishes of Europe, Aula-Verlag Wiesbaden, vol. 2, 89-126.

QUIGNARD J.P., DOUCHEMENT C., 1991b. Alosa fallax fallax (Lacépède, 1803). In : HOESTLANDT $\mathrm{H}$. (ed.), The Freshwater Fishes of Europe, Aula-Verlag Wiesbaden, vol. 2, 225-256. 